Annals of Warsaw University of Life Sciences - SGGW

Land Reclamation No 46 (4), 2014: 353-361

(Ann. Warsaw Univ. Life Sci. - SGGW, Land Reclam. 46 (4), 2014)

\title{
The upper Odra as a case study of the impact of channel regulation on its morphodynamics
}

\section{AGNIESZKA CZAJKA}

Faculty of Earth Sciences, University of Silesia

\begin{abstract}
The upper Odra as a case study of the impact of channel regulation on its morphodynamics. The aim of the research was to compare morphodynamics of the Odra river channel in three different sectors and to find the main difference in the way of sediment transport before and after regulation in meandering, straight and sinuous channel sectors and compare the data with those calculated for reconstructed, natural channel of the Odra river. Sediment transport in discussed sectors was compared for average, bankfull and flood discharges and it proceeds in different ways. Morphodynamics of the preregulated Odra was most similar to the one currently observed in the meandering section. Also the dynamics of bed-material transport and, consequently, the possibility of the occurrence and disappearance of channel forms is greatly varied among the studied sectors. As it was assumed, a diversified channel geometry imposes water flow, which entails a series of processes shaping the channel dynamics.
\end{abstract}

Key words: morphodynamics, river regulation, sediment transport, hydrogeometry

\section{INTRODUCTION}

Studies on the nature of river bottom forms started in the 1960s (Simons, Richardson, 1966). There are popular works in this topic by Allen (1965), Carling (2000) and Kleinhans $(2002,2005)$ focused on the conditions of bottom forms formation, their dynamics, a bedload particle size and morphometry and especially on the hydrodynamic conditions in which bedforms may develop and exist. Literature review shows that the development of bottom forms, which are an important part of the riverbed morphology, favours a constant flow (Kleinhans, 2001). The formation of benthic forms also depends on the size of the transported mineral grains (Dietrich, 1982). In large lowland rivers like the Rhine bedforms have a significant size reaching up to tens of metres and are named dunes. In smaller rivers, their sizes range from a few to tens of centimetres. The studies of bedforms in navigable stretches of the river are more popular, because the accumulation of a large amount of bottom material can shallow the waterway and in some cases make shipping impossible. This phenomenon may occur especially during low water levels (Zanke, 2003). Depending on the channel slope dunes in a lowland river move from a few to tens of meters per day (Radecki-Pawlik et al., 2006). All of these studies analyze only the present state, while the objective of this work is to determine how far the contemporary morphodynamics of 
the upper Odra channel differs from the natural state.

Frings et al. (2009) traced the direction of changes in sediment grain size building sandbars in the Waal river bottom in the Netherlands. It was found that over the past 900 years the average particle diameter of the bedload material decreased, which is directly linked with the embankments of the river and the construction of groins keeping the flow far from the river banks, the increasing flow rate and the change in the nature of the material supplied to the Rhine. In these studies sediments from the former natural sections of the Waal river bed were analyzed in order to reconstruct the natural structure of the river bottom. A reconstruction of natural processes in the river channel could be based only on calculations. In case of the upper Odra the significance of the change in the nature of river channel dynamics depends on the degree of human pressure (Czajka 2008, Ciszewski, Czajka 2009). The model of the morphodynamics of natural river channel may be compared with the model derived from the studies of the upper Odra in regulated sectors. Some differences in the channel dynamics are possible as a result of present different environmental conditions, such as catchment management affecting the nature of the material supplied to the Odra river.

\section{MATERIAL AND METHODS}

The aim of the research was to reconstruct natural morphodynamics of the Odra river channel and to find the main difference in the nature of sediment transport before and after regulation.

For that purpose:

- the morphodynamics of the current channel in sections of different nature was characterised,

- the geometry of the Odra pre-regulated channel section was reconstructed,

- the morphodynamics of pre-regulated channel was characterised,

- the most important changes in the river behaviour caused by the channel regulation were indicated.

Following the analysis of cartographic data detailed study sites were selected to do research on morphodynamics of the upper Odra channel (Fig.1). Among the Odra sectors chosen for the study there was three between the Chałupki and the Nieboczowy: meandering - sector A, channelized - sector B, sinuous - sector $\mathrm{C}$, and additional one, not existing at present, between the Grzegorzowice and the Lasaki - sector D.

Sector D was chosen on the basis of cartographic analyses. In this selected fragment of the channel meanders were cut off simultaneously, shortly after the beginning of regulation works in the upper Odra in 1786-1820 (Fig. 2).

The morphology of the Odra riverbed in sectors A, B and C was identified through a series of echograms conducted with Lowrance HDS- 5 echosounder and also a structure scanner. The geometry of the D reference channel was reconstructed with cartographic and geodetic methods and by series of bores in the cut-off meanders. 

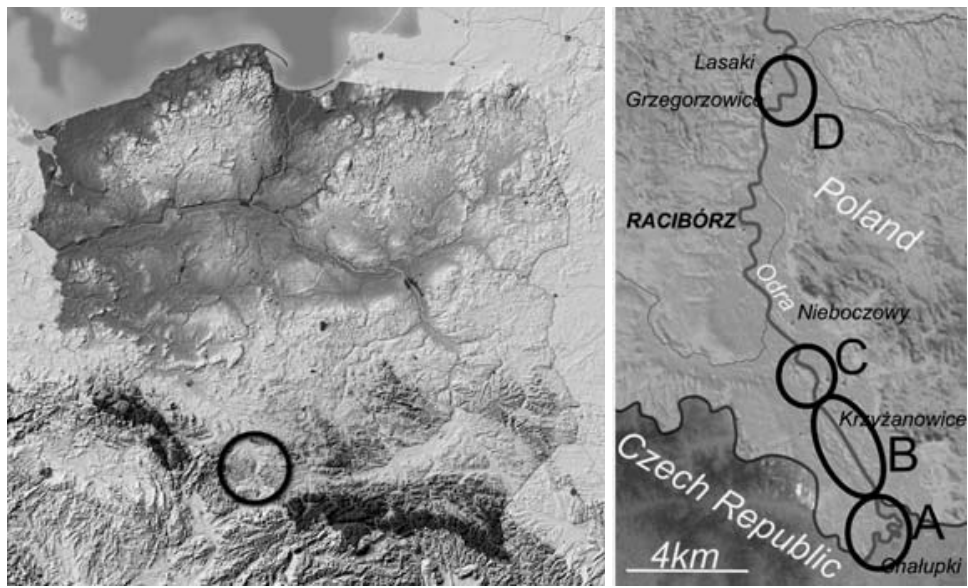

FIGURE 1. Poland with location of upper Odra and study sites along the upper Odra channel

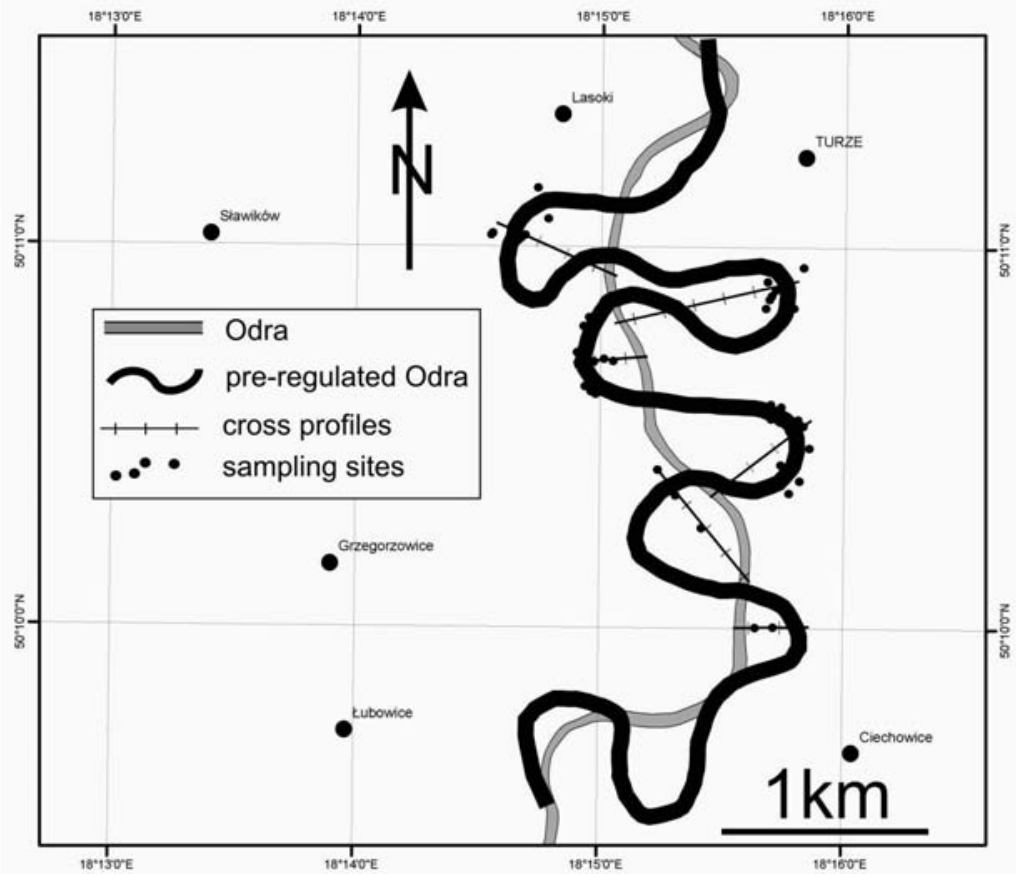

FIGURE 2. Sector D. Meanders cut offs and the sampling sites

In all the sections samples of bottom load were taken and they underwent a standard granulometric analysis. Sediment was taken with an Eikelkamp's hand auger in the reference section.
To establish the channel stability and dynamics parameters as hydraulic radius $(R)$, flow velocity $(v)$, shear stress $(\tau)$, Bonnefille particle number $\left(D^{*}\right)$, Shields mobility number $(\theta)$, potencial 


\begin{tabular}{|c|c|c|c|c|c|c|c|c|c|c|c|c|c|c|c|c|c|c|c|c|c|c|}
\hline & & 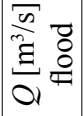 & & 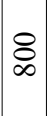 & $r$ & $\begin{array}{l}\infty \\
\infty \\
0 \\
0\end{array}$ & $\hat{n}$ & $\tilde{n}$ & $\stackrel{n}{0}$ & & $\left|\begin{array}{l}0 \\
\infty \\
\infty \\
\sim\end{array}\right|$ & $\bar{n}$ & 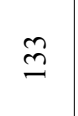 & & $\begin{array}{l}\hat{b} \\
\dot{0}\end{array}$ & t & in & $\begin{array}{l}0 \\
\dot{i} \\
\mathrm{~N}\end{array}$ & 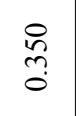 & ฉ & 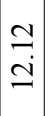 & $\stackrel{6}{6}$ \\
\hline & $\begin{array}{l}0 \\
\dot{0} \\
\dot{0} \\
\tilde{D} \\
\tilde{L}\end{array}$ & 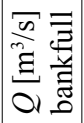 & & $\begin{array}{l}2 \\
\infty\end{array}$ & $\nabla$ & $\begin{array}{l}\hat{\infty} \\
\dot{m}\end{array}$ & $\stackrel{n}{\sim}$ & $\hat{\tilde{o}}$ & $\stackrel{n}{a}$ & & $\begin{array}{l}n \\
f \\
f\end{array}$ & $\begin{array}{l}\text { ț } \\
\stackrel{0}{0}\end{array}$ & in & & $\begin{array}{l}\tilde{b} \\
\stackrel{0}{0}\end{array}$ & $\nabla$ & in & 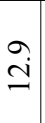 & 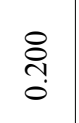 & ㅇ & $\begin{array}{c}\mathrm{I} \\
\stackrel{\mathrm{I}}{\mathrm{i}}\end{array}$ & $\stackrel{\square}{\pi}$ \\
\hline & & 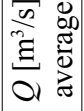 & & 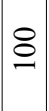 & $\stackrel{0}{-}$ & 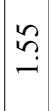 & $\stackrel{n}{\sim}$ & m. & $\stackrel{n}{0}$ & & in & ?n. & 9 & & $\begin{array}{l}\hat{\mathscr{b}} \\
\stackrel{0}{0}\end{array}$ & t & in & 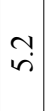 & $\begin{array}{l}8 \\
\stackrel{0}{0} \\
\stackrel{0}{0}\end{array}$ & ஃ & 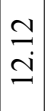 & ণָ \\
\hline & & 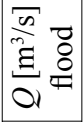 & & $\begin{array}{l}n \\
\tilde{n} \\
\tilde{N}\end{array}$ & $\frac{t}{\sigma}$ & $\begin{array}{l}\grave{\alpha} \\
\infty\end{array}$ & $\because$ & $\begin{array}{l}\infty \\
0 \\
0\end{array}$ & $\tilde{0}$ & & $\mid \begin{array}{l}\infty \\
\infty \\
\infty \\
\sim\end{array}$ & ત્ & 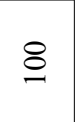 & & $\begin{array}{l}n \\
0 \\
0\end{array}$ & ナ & in & ?ై & $\begin{array}{l}\overline{0} \\
n \\
0\end{array}$ & ฉ & $\begin{array}{l}n \\
\tilde{o} \\
0\end{array}$ & $\bar{n}$ \\
\hline & $\begin{array}{l}0 \\
\dot{0} \\
0 \\
\tilde{U} \\
\mathscr{n}\end{array}$ & 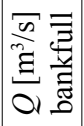 & & $\begin{array}{l}\dot{\theta} \\
\dot{\theta}\end{array}$ & $\begin{array}{l}\hat{\sigma} \\
\dot{n}\end{array}$ & $\begin{array}{l}\dot{D} \\
\dot{+}\end{array}$ & $\because$ & ?. & $\because$ & & $\begin{array}{l}\stackrel{n}{f} \\
f\end{array}$ & సి & $\vec{\gamma}$ & & $\begin{array}{l}n \\
0 \\
0\end{array}$ & $\nabla$ & in & $\overrightarrow{\dot{\lambda}}$ & $\begin{array}{l}\text { స్ } \\
\text { ஸి } \\
0\end{array}$ & ฉ & $\begin{array}{l}n \\
n \\
0 \\
0\end{array}$ & $\begin{array}{l}\infty \\
\infty \\
\text { ते }\end{array}$ \\
\hline & & 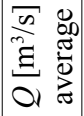 & & $\underset{\sim}{\infty}$ & nิ & $\stackrel{\substack{q \\
\hdashline}}{-}$ & $\because$ & $\begin{array}{l}\infty \\
0 \\
0\end{array}$ & $\because$ & & $\mid \begin{array}{l}0 \\
i \\
i \\
n\end{array}$ & $\frac{m}{0}$ & $\Xi$ & & 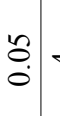 & $\nabla$ & in & $\hat{\vec{n}}$ & $\begin{array}{l}\text { ô } \\
\text { ơ }\end{array}$ & ฉ & $\begin{array}{l}n \\
n \\
0 \\
0\end{array}$ & $\frac{\hat{\sigma}}{\dot{m}}$ \\
\hline & & 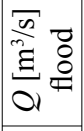 & $\left|\begin{array}{l}30 \\
0 \\
0 \\
0 \\
2 \\
2\end{array}\right|$ & $\stackrel{0}{2}$ & $\hat{\sigma}$ & $\begin{array}{l}2 \\
0 \\
0 \\
0\end{array}$ & $\stackrel{I}{\beth}$ & $\stackrel{t}{0}$ & $\stackrel{\infty}{+}$ & : & $\mid \begin{array}{c}8 \\
\infty \\
\sim \\
\sim\end{array}$ & $\tilde{n}$ & 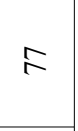 & 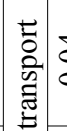 & $\begin{array}{l} \pm \\
0 \\
0\end{array}$ & $m$ & \& & $\begin{array}{l}\infty \\
\infty \\
\infty \\
\infty\end{array}$ & $\begin{array}{l}8 \\
\infty \\
\infty \\
0\end{array}$ & $\hat{\sigma}$ & in & nิ \\
\hline & $\begin{array}{c}n \\
\dot{0} \\
\stackrel{0}{0} \\
\stackrel{\Delta}{n}\end{array}$ & 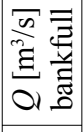 & 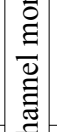 & 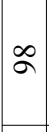 & $\stackrel{9}{r}$ & $\begin{array}{l}8 \\
0 \\
0\end{array}$ & $\stackrel{\cong}{\leftrightarrows}$ & $\stackrel{t}{0}$ & $\stackrel{\infty}{+}$ & $\mid \begin{array}{c}0 \\
0 \\
0 \\
z \\
0 \\
\underline{I}\end{array}$ & 导 & $\begin{array}{l}\vec{\sigma} \\
0\end{array}$ & nి & 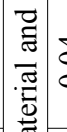 & $\begin{array}{l}+ \\
\stackrel{0}{0}\end{array}$ & $m$ & \& & $\stackrel{0}{\dot{m}}$ & 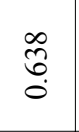 & $\hat{\sigma}$ & $\begin{array}{l}\stackrel{0}{n} \\
r \\
r\end{array}$ & $\underset{\beth}{J}$ \\
\hline & & 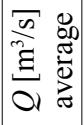 & & $\begin{array}{c}1 \\
\hat{6}\end{array}$ & $\stackrel{\infty}{-}$ & $\stackrel{?}{i}$ & $\stackrel{\cong}{\leftrightarrows}$ & t. & 文. & & $\begin{array}{l}0 \\
\dot{n} \\
i\end{array}$ & $\stackrel{a}{\stackrel{a}{0}}$ & $=$ & $\Sigma$ & $\begin{array}{l}\dot{0} \\
\dot{0}\end{array}$ & $m$ & \& & $\vec{\pi}$ & $\frac{\stackrel{n}{ \pm}}{\circ}$ & $\hat{\sigma}$ & $\begin{array}{l}\stackrel{0}{n} \\
r \\
r\end{array}$ & $\begin{array}{l}\stackrel{2}{\partial} \\
\infty \\
0\end{array}$ \\
\hline & & 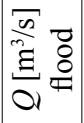 & & $\stackrel{\infty}{\underset{工}{\simeq}}$ & $\stackrel{2}{ָ}$ & fே. & $\stackrel{n}{\sim}$ & חి & $\frac{n}{0}$ & & $\begin{array}{c}8 \\
\stackrel{8}{N}\end{array}$ & $\begin{array}{c} \pm \\
i \\
i\end{array}$ & $\cong$ & & 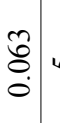 & in & 8 & $\begin{array}{l}m \\
\tilde{v}\end{array}$ & 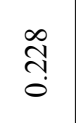 & $\stackrel{\cong}{\Xi}$ & \begin{tabular}{l}
$n$ \\
\hdashline \\
$n$
\end{tabular} & $\begin{array}{l}\infty \\
\infty \\
\end{array}$ \\
\hline & 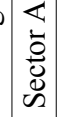 & 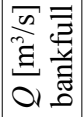 & & $\begin{array}{l}1 \\
\infty \\
\infty \\
0\end{array}$ & $\begin{array}{l}0 \\
\dot{+}\end{array}$ & $\begin{array}{l}n \\
\tilde{+} \\
\dot{\gamma}\end{array}$ & $\stackrel{n}{\sim}$ & ?ֶ. & $\begin{array}{l}n \\
\stackrel{2}{0}\end{array}$ & & $\stackrel{2}{2}$ & 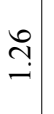 & $\stackrel{q}{q}$ & & $\begin{array}{l}\hat{\mathscr{b}} \\
\stackrel{0}{0}\end{array}$ & in & 8 & $\underset{\dot{J}}{g}$ & $\frac{+}{\stackrel{\infty}{0}}$ & $\stackrel{\beth}{\Xi}$ & $\frac{n}{n}$ & $\frac{a}{\stackrel{+}{d}}$ \\
\hline & & 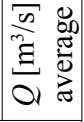 & & 8 & $\underline{\hat{\sigma}}$ & 年 & $\stackrel{m}{\sim}$ & $\tilde{n}$ & $\frac{n}{o}$ & & $\frac{m}{q}$ & $\stackrel{\mathcal{I}}{\circ}$ & 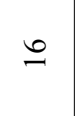 & & $\begin{array}{l}\hat{b} \\
\stackrel{0}{0}\end{array}$ & in & 8 & $\begin{array}{l}m \\
n\end{array}$ & $\begin{array}{l}n \\
\stackrel{2}{0} \\
0\end{array}$ & $\stackrel{\cong}{\Xi}$ & $\begin{array}{l}n \\
n \\
n\end{array}$ & $\frac{n}{\pi}$ \\
\hline & & 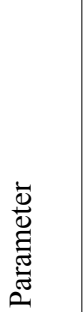 & & 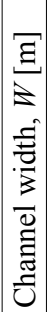 & 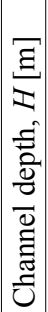 & 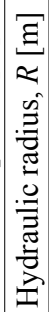 & 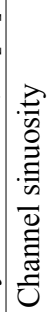 & 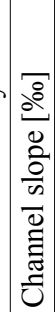 & $\begin{array}{l}\frac{8}{2} \\
\frac{\partial}{0} \\
\frac{0}{0} \\
\frac{0}{n} \\
\frac{0}{2} \\
\frac{1}{\pi}\end{array}$ & & 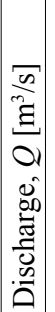 & 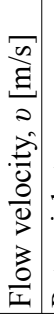 & 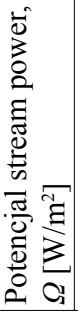 & & 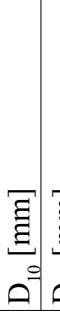 & 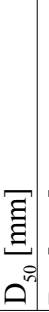 & $\begin{array}{c}\bar{\Xi} \\
a^{\circ} \\
\end{array}$ & 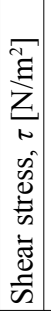 & 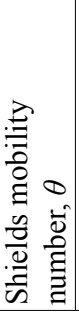 & 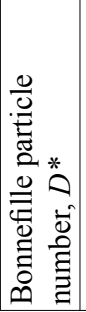 & 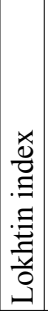 & 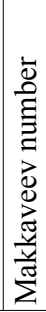 \\
\hline
\end{tabular}


stream power $(\Omega)$ were calculated for each section (Table 1).

Inaddition,Lochtin'sandMakkaveev's indexes, little popular in the subject literature but useful to determine river channel stability, were calculated (Table 2).

The parameters determining the channel stability were divided into three groups regarding the flow, material transfer and the channel morphology respectively. All the parameters were then calculated for each of the selected sectors (meandering - A, channelized $-\mathrm{B}$ and sinuous $-\mathrm{C}$ ) and for the reconstructed, natural sector
$\mathrm{D}$, the parameters of which were calculated on the basis of the measurements of the Odra channel geometry prior to regulation. The values of parameters for each section were additionally divided into three groups - for the average, bankfull and flood discharge conditions.

\section{RESULTS AND DISCUSSION}

The analyses of grain-size distribution of bottom load, channel geometry and flow rate allowed to estimate flow conditions in which material is transported in different ways (Fig. 3). In the mean-

TABLE 2. Channel stability in studied sectors of Odra channel by Lokchtin $(\eta L)$ and Makkaveev $(\eta M)$ respectively for: 1 - average discharge, 2 - bankfull discharge, 3 - flood discharge

\begin{tabular}{|c|c|c|c|c|c|c|c|c|c|c|c|c|}
\hline \multirow{2}{*}{$\begin{array}{l}\text { Para- } \\
\text { metr }\end{array}$} & \multicolumn{3}{|c|}{ Sector A } & \multicolumn{3}{c|}{ Sector B } & \multicolumn{3}{c|}{ Sector C } & \multicolumn{3}{c|}{ Sector D } \\
\cline { 2 - 14 } & 1 & 2 & 3 & 1 & 2 & 3 & 1 & 2 & 3 & 1 & 2 & 3 \\
\hline$\eta L$ & 15.15 & 15.15 & 15.15 & 7.5 & 7.5 & 7.5 & 10.53 & 10.53 & 10.53 & 12.12 & 12.12 & 12.12 \\
\hline$\eta M$ & 27.5 & 24.19 & 12.89 & 18.99 & 12.24 & 1.59 & 31.67 & 22.89 & 6.51 & 13.2 & 7.14 & 1.65 \\
\hline
\end{tabular}

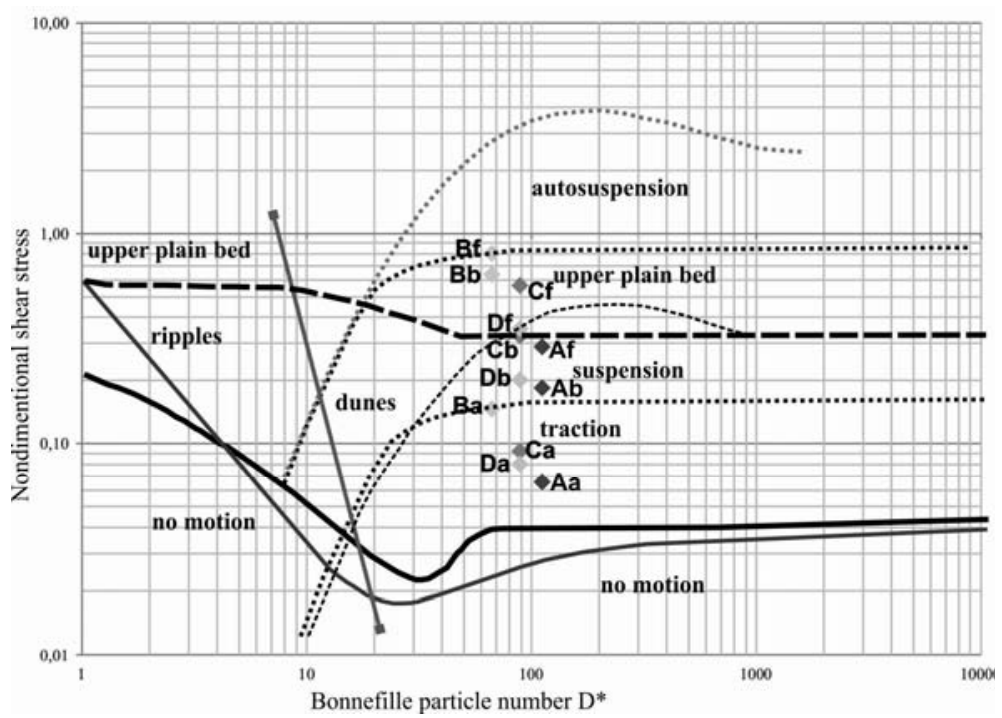

FIGURE 3. Sediment movement in studied sectors of Odra river during average water stage, bankfull water stage and during the flood. A - meandering sector, B - channelized sector, C - sinuous sector, $\mathrm{D}$ - reference sector; $\mathrm{a}$ - average discharge, $\mathrm{b}$ - bankfull discharge, $\mathrm{f}$ - flood. Compilation of curves after Kleinhans (2005) 
dering sector $-\mathrm{A}$ in average water stages the material is transported in traction, whereas when the water level rises, both during bankfull and flood levels the material breaks off from the bottom and is transported in suspension. In this section the creation of bottom forms is possible only during high water levels. After high water level subsides the emerged forms function in this area as numerous side bars.

The channelized sector - B is distinguished by different transport dynamics. Already in average water stages the material is picked up from the bottom, while in bankfull and flood water stages all bottom forms are washed out. In fact the forms which emerge and are built up in subsequent floods reveal themselves as central bars when water level goes back to average, while in the following floods they function as bottom forms and are washed out. Another problem interfering with transport dynamics and preventing the river from striking a new balance in this section is continuous human activity, which consists in removing bedload from the Odra bottom and excavating newly-emerged sandbars from the channel after each flood.

The sinuous sector $-\mathrm{C}$, which follows the channelized section in the river course, is strongly affected by the latter one. A negative budget of the material transport caused by human activity relieves water of the transported material and results in the lack of bottom forms. The energy of flow does not allow the material to deposit on the bottom. In addition, the current, which is kept away from the river banks with groynes, is concentrated and causes channel incision. The material carried away from the channelized section is deposited on the first meander of the sinuous section. It is the last sandbar in the examined part of the Odra and the only one in the sinuous section. In this section during the average water level the material is transported in traction, like in the meandering section. But in bankfull and flood water levels all bottom forms are washed out.

Having analysed material transport dynamics in the three sections of the Odra channel, their course was compared with the processes occurring in the preregulated channel (sector D). To achieve this a reference section was marked out, within which there are six subsequent meanders cut off during regulation. The geometry of the pre-regulated fragment of the Odra channel was reconstructed through cartographic and field measurements and a series of drillings. The difference in width, exceeding even $100 \mathrm{~m}$, is the biggest difference compared to the contemporary geometry of the Odra channel. Reference material from the bottom of meanders of the former channel was collected and the same calculating procedure as for the sectors - A, B and $\mathrm{C}$ was applied to it. As far as material transport dynamics is concerned, sector D mostly resembles contemporary sector A with the difference that in flood flows a part of forms could have 
been partly washed out, which does not occur in the present sector $\mathrm{A}$. The reason of that difference is the bottom material size which is finer in sector $D$ than in sector A. During average water stages the material was rolled along the river bed, in bankfull stages it was lifted up, while in case of flood there appeared the so-called upper plain bottom.

According to Lochtin's index, the channel in the meandering sector $-\mathrm{A}$ is stable, in the channelized sector $-\mathrm{B}$ is quite stable, while in the sinuous sector - C the stability reaches the lower value established for stable channels, which is, at the same time, most similar to the stability of pre-flood channel (sector D).

The results of calculations with the use of Makkaveev's formula should be considered more reliable as it involves more variables. Owing to that the channel stability can be estimated not only for the average but also for bankfull and flood water stage. The results of the calculations clearly indicate that the channel stability decreases when the water level rises. Sectors A and C are most stable during average and bankfull stages. Sector B reveals the smallest stability as, against the assumptions of regulation, it becomes an unstable channel during floods and a low-stability channel in bankfull discharges.

The dynamics of bed-material transport and, consequently, the possibility of the occurrence and disappearance of channel forms is greatly varied among the studied sections. As it was assumed, a diversified channel geometry imposes water flow, which entails a series of processes shaping the channel dynamics.

The comparison of riverbed morphology, bottom load transport conditions, the possibilities of washing out of channel forms and the channel stability in the examined sections allows to draw a conclusion that these sections strongly influence one another. Channelized sector - B acts as a kind of catalyst of transport dynamics modification in the entire part of the Odra subject to this study. In some of its parts the channel is up to 6-meter deeper than in sectors A and $\mathrm{C}$ and the rest of sector $\mathrm{D}$. The deepening is the result of illegal excavation of gravel and sand from the riverbed and it is easily visible in echograms generated during the studies as a deep, local excavation pit.

\section{CONCLUSIONS}

The upper Odra is distinguished by varied morphodynamics. These variations in channel stability and in the way of material transport are an effect of differences in the geometry of the river channel obtained as a result of river regulation. Additionally, in sector A the bedload is coarser since it is supplied from upstream where the Odra channel is regulated in the Czech Republic. On the contrary, the finest material was found in sector B. because of gravel excavation from the riverbed. Also the dynamics of the regulated sections of the channel differs from the dynamics of the natural and reference section to a great extent. 
Morphodynamics of the pre-regulated Odra was most similar to the one currently observed in the meandering section, however the channel of the preregulated Odra section was considerably less stable during floods, which may result from a higher content of fine fraction in the bedload that makes up the riverbed in the reference section.

\section{Acknowledgments} Project was funded by MNiSW/NCN
under grant N N306 119038 .

\section{REFERENCES}

ALLEN J.R.L. 1965: A review of the origin and character of recent alluvial sediments. Sedimentology 5: 89-191.

CARLING P.A., GOELZ E., ORR H.G., RADECKI-PAWLIK A. 2000: The morphodynamics of fluvial sand dunes in the River Rhine near Mainz, Germany. I. Sedimentology and morphology. Sedimentology 47: 227-252

CISZEWSKI D., CZAJKA A. 2009: Akumulacja osadów na równinach zalewowych rzek silnie zmienionych antropogenicznie: górna Wisła i Odra. Prz. Geol., 57: 576-583.

CZAJKA A. 2008: River response to channel regulation, Upper Odra River, Poland. [In:] B. Gumiero, M. Rinaldi, B. Fokkens (Eds). 4th International Conference on River Restoration, European Centre for River Restoration, Venice: $431-436$.

DIETRICH W. 1982: Settling velocity of natural particles. Water Resour. Res. 18(6): 1615$-1626$.

FRINGS R.M., BERBEE B.M., ERKENS G., KLEINHANS M.G., MARC J.P., GOUWB M.J.P. 2009: Human-induced changes in bed shear stress and bed grain size in the River Waal (The Netherlands) during the past 900 years. Earth Surf. Process. Landforms 34: 503-514.
KLEINHANS M.G. 2001: The Key Role of Fluvial Dunes in Transport and Deposition of Sand-Gravel Mixtures, a preliminary note. Sedimentary Geology 143 (1-2): 7-13.

KLEINHANS M.G. 2002: Sorting out sand and gravel: sediment transport and deposition in sand-gravel bed rivers. Universiteit Utrecht, PhD Thesis, Utrecht.

KLEINHANS M.G. 2005: Flow discharge and sediment transport models for estimating a minimum timescale of hydrological activity and channel and delta formation on Mars. J. Geophys. Res. 110, E 12003.

MAKKAVEEV N.I. 1976: General regularities of erosion-channel processes [In:] Channel processes. Proceedings of the 4 All - Union Hydrological Congress, 10, L., Gidrometeoizdat: 8-12.

RADECKI-PAWLIK A., CARLING P., GÖLZ E. 2006: Budowa granulometryczna i geometryczna form dennych rzeki nizinnej rzeki Ren. Infrastruktura i ekologia terenów wiejskich, PAN, Oddział w Krakowie 2/1: 15-32.

SIMONS D.B., RICHARDSON E.V. 1968: Resistance to flow in alluvial channels. U.S. Geol. Surv. Profess. Papers 422-J.

ZANKE U.C.E. 2003: On the influence of turbulence on the initiation of sediment motion. Int. J. Sediment Res. 18(1): 1-15.

Streszczenie: Wpływ regulacji koryta na jego morfodynamike na przyktadzie górnej Odry. Celem badań jest porównanie morfodynamiki koryta Odry w trzech różnych odcinkach $\mathrm{w}$ celu wychwycenia różnic w sposobie transportu materiału przed regulacją i po regulacji koryta w odcinkach meandrującym, prostym i krętym oraz porównanie uzyskanych danych $\mathrm{z}$ danymi otrzymanymi dla koryta przedregulacyjnego. Transport materiału w omawianych odcinkach był porównywany dla przepływów średnich, pełnokorytowych i powodziowych. Morfodynamika przedregulacyjnego koryta Odry była najbardziej podobna do obecnie obserwowanej $\mathrm{w}$ korycie meandrowym. Dynamika transportu materiału dennego, a w konsekwencji powstawanie i rozmywanie form korytowych jest zróżnicowane w badanych odcinkach. Zgodnie z założeniami wykazano, że zmodyfikowana geometria koryta 
The upper Odra as a case study of the impact.. 361

Odry różnicuje przepływ wody, co z kolei pociąga za sobą różnice we współczesnych procesach kształtowania koryta.

Słowa kluczowe: morfodynamika, rzeka uregulowana, transport rumowiska, hydrogeometria

MS. received July 2014
Authors' addresses:

Agnieszka Czajka

Katedra Rekonstrukcji Środowiska Geograficznego Wydział Nauk o Ziemi

Uniwersytet Śląski

ul. Będzińska 60, 41-200 Sosnowiec

Poland

e-mail: agnieszka.czajka@us.edu.pl 